\title{
STUDY THE VARIATION OF SUGAR BEET Rhizoctonia solani BY PCR (rDNA-ITS SEQUENCES) \\ Nour-El-Din, Mona M.S. ${ }^{1}$; M. M. E.Saleh ${ }^{1}$ and E. E. Hafez ${ }^{2}$ \\ 1 Plant pathology Res. Inst. ARC, Giza, Egypt. \\ 2 Arid Land Res. Inst., Mubarak City For Res., Alexandria Egypt.
}

\begin{abstract}
Rhizoctonia solani Kühn, teleomorph Thanatephorus cucumeris (Frank) Donk is one of the important sugar beet soil borne pathogen and can damage any part or all of a plant. Isolates divided into types or groups $\left(\mathrm{AG}_{\mathrm{s}}\right)$ based on the anastomosis behaviour of individual isolates. Crown and root rot is primarily caused by AG2-2, while damping-off in seedling and foliar blight signs are generally attributed to AG4. the various AG types represent genetic deversity within the species. Three $R$. solani isolates collected from different localities at West-Nubaria region, showing characteristic sugar beet crown and root rot symptoms, were chosen and compared to the well- characterized $R$. solani (tweleve isolates) obtained from different hosts.

All fifteen $R$. solani tested isolates observed show different levels of pathogenicity by inducing chlorosis, wilting, crown rot, root rot and damping-off on inoculated sugar beet. Data based on the morphological characteristices of the pathogen, pathogenicity tests, hyphal compatibility reaction and sequencing analysis of the ITS region (internal transcribed spacer) of ribosomal DNA of the tested isolates in order to detect their relatedness. Sequence analysis showed that these isolates were varied genetically, where data could be genotype them into two main clusters including AG2-2 and AG4 groups. Additionally, phylogenetic tree recorded the relationship between ITS sequence of rDNA for those tested isolates.
\end{abstract}

Keywords: Sugar beet, Rhizoctonia solani, anastomosis groups, PCR (rDNA, ITS region).

\section{INTRODUCTION}

Rhizoctonia solani Kuhn, teleomorph Thanatephorus cucumeris (Frank) Donk is a soil borne fungus with a worldwide distribution. This specy is highly heterogeneous and causes damping-off, root rot and foliar blight symptoms on many plant species. Rhizoctonia root and crown rot is far the most common and serious of these diseases for sugar beet production in many growing areas. The pathogen causes some pre-emergence death of seedlings but inflicts most of its damage on emerged seedlings. Infection is initiated below the soil surface and extends up the hypocotyl, with a sharp margin between infected and healthy tissue. Lightly infected seedlings often survive and may produce nearly normal roots. The same fungus, however, may later in the season cause crown rot or dry rot canker on maturing roots (Whitney and Duffus, 1986).

Rhizoctonia is typically a sterile fungal genus and has been characterized by division into binucleate and multinucleate groups. $R$. solani is multinucleate and on the basis of hyphal anastmosis between different isolates, it is divided into 14 anastomosis group: AG 1-13 and AG BI (Carling et al., 2002).Groups $-1,-2,-3,-4,-6,-7,-8$ and -9 are additionally divided into subsets (intraspecific groups) based on their morphological characteristics, 
frequency of hyphal fusion, virulence, host range, nutritional requirements, biochemical characteristics, thiamine requirement, peptic isozymes, fatty acids and molecular characteristics (Carling et al.,2002 ,Fenille et al.,2003, Guillemaut et al.,2003, Sharma et al.,2005, Mahmoud et al.,2007 and Stojsin et al.,2007). On sugar beet, this pathogen can invade any part of the plant, According to Windels and Nabben,1989. R. solani anastomosis group -1,-22,-4 and -5 can cause damping-off. Additionally, AG-3 and AG-5 were isolated from sugar beet with symptoms of dark discoloration on petiole basis (Windels et al.,1997).

The causal agent of Rhizoctonia crown and root rot of sugar beet is typically characterized as belonging to AG2-2 with individual isolates being placed into intraspecific group IIIB and IV. Both of these intraspecific groups are found worldwide although AG2-2 III B is more common on sugar beet in Europe in rotation with maize (Jacobsen, 2005).Other studies of Minnesota University revealed that AG2-2 isolates were the most highly pathogenic to sugar beet producing root and crown rot as well as causing damping-off but not foliar blight. Otherwise AG-4 causes damping-off and foliar blight but would not cause root or crown rot and it is widely held that strains of AG-4 have broad host ranges. However, studies are needed to determine whether individual strains might have narrower host ranges than attributed to AG-4as a whole. In Idaho state, AG-4 was isolated from potatoes without appearing damage to it. It was indicated that potatoes damages were attributed to AG-3 but it was not pathogenic to sugar beet (Windels et al.,1997 and Kuningaga et al.,2000).

Recently, besides the system of anastomosis grouping of $R$. solani isolates based on hyphal fusion, different molecular methods have been developed and proven to be very useful for analysis of the evolutionary homology between isolates in the $R$. solani complex. Polymorphisms in soluble protein patterns were described among $11 \mathrm{AG}_{\mathrm{s}}$ of $R$. solani .Nevertheless, isolates containing of one particular AG or sub group had a similar banding pattern, although they represented different geographical regions, host plants or pathogenicity (Liu et al.,1995). It was also reported that $R$. solani isolates obtained from various rice-growing countries representing different $A G_{s}$, showed very distinguishable patterns based on analysis of pectin enzymes, as well as RFLP analysis of A+T-rich DNA (Banniza and Rutherford, 2001). Genetic heterogenicity between, and within anastomosis groups was evaluated by Fenill et al.,(2003) using sequence analysis of the internal transcribed spacer (ITS) region of the ribosomal DNA. Comparison of the ITS region is significant not only for the determination of anastomosis groups, but these sequences are also useful for verifying subsets. Polymorphism between $\mathrm{AG}_{\mathrm{s}}$ was revealed in the ITS1 and ITS2 sequences of ribosomal DNA, while 5.8s rDNA sequence is completely conservative across all AGs $_{\text {s }}$ (Kuninaga et al.,1997 and 2000, Gonzales et al.,2006. The behaviour of commercial varieties, especially the imported of sugar beet in Egypt against the studied pathogen is still not well defined and needs more investigation.

In this study, the ITS regions of fifteen R.solani isolates, which originated from various invaded hosts were analysed in order to determine 
sequence variations between them, and to identify the anastomosis group otherwise subsets of such examined isolates.

\section{MATERIALS AND METHODS}

\section{Pathogen isolation and collection:}

Fifteen isolates of Rhizoctonia solani were isolated and collected from different infected plant hosts. Three of these isolates were isolated from sugar beet plants suffered from typical symptoms of Rhizoctonia crown and root rot obtained from different fields belongs to new reclaimed lands, West Nubaria region. One another isolate was isolated from severed rotted potato plant and the rest eleven various isolates were collected from different infected hosts: alfalfa, bean, tomato, pea, pepper, sorghum, soybean, maize and water melon. Isolates were purified on PDA medium and maintained at $28^{\circ} \mathrm{C}$. Identification of these isolates was confirmed with reference strains of this pathogen.

\section{Pathogenicity Tests:}

Each isolate was grown separetely in glass bottle $(500 \mathrm{~mL})$ containing $(200 \mathrm{~g})$ barley grains medium as it is favourable for mycelial growth and multiplication. Inoculated bottles were incubated at $28-30^{\circ} \mathrm{C}$ for 14 days. Sterilised sandy-clay soil was infested 1 week before sowing, at the rat of $2 \%$ inoculum per $100 \mathrm{~g}$ soil.

Test.1. Inoculation process were carried out by four $R$. solani isolates, three obtained from sugar beet and one from potato infected plants, in order to detect damping- off symptoms on sugar beet seedlings (seed rot, wilting, pre and post- emergence) symptoms were recorded 15-45 days after sowing. Percentage of uninfected (Healthy) plants was calculated as follows:

$\%$ Healthy plants $=\frac{\text { Number of healty plants }}{\text { Total plants number }} X 100$

Test.2. Inoculation process carried out by all fifteen $R$. solani isolates obtained from different hosts within the four previous isolates used before, which by sugar beet plants were infected near the base of stems. Plants were assessed for chlorosis, wilting, stunting, crown and root rot respectively: Control treatments have not received any pathogen inoculum. Treatments were treplicated. Soil was kept moisturized for allowing mycelial growing and dispersion. Tests was carried out on Beta vulgaris (Athospoly varietyMultigerm) [origin: EU/Belgium] seeds.

\section{Compatibility Test:}

All obtained $R$. solani isolates either isolated from sugar beet or those isolated from different plant hosts were tested for anastomosis reaction. These isolates (fifteen) were then paired in all combinations on PDA to identify compatible isolates. Mycelial compatibility was determined using the method of Earnshaw \& Boland ,(1997). Inoculum plugs (5mm in diameter) were placed $7-\mathrm{cm}$ apart on $9-\mathrm{cm}$ PDA Petri dishes, incubated at $28^{\circ} \mathrm{C}$ in pairs 
Nour-EL-Din, Mona M.S. et al.

of isolates and were recorded 3 days later for both compatible and incompatible reactions. Compatible reaction $(+)$ were recorded if the two tested colonies merged without forming a dark line or a strip of thin mycelium. Incompatible reactions (-) were carried out when a reaction line formed between the examined colonies.

\section{DNA Isolation:}

Prior to DNA extraction, $R$. solani tested isolates were each grown in $(50 \mathrm{~mL})$ of potato dextrose broth (Difco) on a rotary shaker at $(120 \mathrm{rpm})$ for 6 days at $25^{\circ} \mathrm{C}$. Mycelial mats were harvested by filtration, blotted dry, and then stored at $\left(-20^{\circ} \mathrm{C}\right)$. Mycelial of each isolate was lyophilized and ground in liquid nitrogen to a fine powder in a prechilled mortar with a pestle ( Innis and Gelfand 1991).

\section{PCR amplification:}

The ITS region of the rDNA was amplified using ITS $1 \mathrm{~F}$ and ITS 4 primers (Table 1). The PCR reaction was performed in $50 \mu$ l total volume consisting of $25 \mu$ l of PCR Master Mix (promega Corporation, Madison, WI, USA), $5 \mu \mathrm{l}$ of $\mathrm{MgCl}_{2}, 2 \mu \mathrm{l}$ of each primer (concentration $10 \mathrm{pmol} / \mu \mathrm{l}$ ), $2 \mu \mathrm{l}$ of DNA template and $14 \mu \mathrm{l}$ of PCR Grade water. The amplification was performed in PCR thermal cycler (Whatman Biometra, Goettingen, Germany). The cycle parameters were as follows: an initial denaturation at $95^{\circ} \mathrm{C}$ for 2 minutes, followed by 38 cycles consisting of denaturation at $95^{\circ} \mathrm{C}$ for 1 minute, annealing at $55^{\circ} \mathrm{C}$ for 45 seconds, and extension at $72^{\circ} \mathrm{C}$ for 1 minute. Final extension was at $72^{\circ} \mathrm{C}$ for 5 minutes. Following the PCR reaction, the amplified products were loaded in a $2 \%$ agarose gel stained with ethidiumbromide, together with 100bp DNA marker (promega corporation,Madison ,WI,USA)Before loading, bothsamples and marker were dyed with Blue/orange $6 \mathrm{X}$ loading Dye used for tracking migration during electrophoresis. Electrophoresis was run at $80 \mathrm{~V}$ for 2 hours. The DNA bands were visualised using Alpha Imager 2200 Imaging System (Alpha Innotech corporation, san Leandro, CA).

Table.1. Primer ITS 1F and ITS 4 sequences, base count, molecular weight, melting temperature and GC content.

\begin{tabular}{|l|l|c|c|c|c|}
\hline & Sequence (5'to3') & $\begin{array}{c}\text { Base } \\
\text { count }\end{array}$ & $\begin{array}{c}\text { Molecular } \\
\text { weight }\end{array}$ & $\begin{array}{c}\text { Melting } \\
\text { temp. }\left({ }^{\circ} \mathbf{C}\right)\end{array}$ & $\begin{array}{c}\text { GC content } \\
(\%)\end{array}$ \\
\hline ITS 1F & $\begin{array}{l}\text { CTT GGT CAT TTA GAG } \\
\text { GAA GTA A }\end{array}$ & 22 & 6813.32 & 56.60 & 36.37 \\
\hline ITS 4 & $\begin{array}{l}\text { TCC TCC GCT TAT TGA } \\
\text { TAT GC }\end{array}$ & 20 & 6033.78 & 61.50 & 45.00 \\
\hline
\end{tabular}

DNA sequencing:

After the amplification of the ITS region of the rDNA, each product was purified using the Qiagen Gel Extraction Kit (Qiagen). The purified rDNA was shipped by overnight mail to DNA Sequencing Facility at Macrogen Inc., Seoul, Republic of Korea., where isolates was sequenced.

Data analysis:

ITS sequences analysis was carried out using CLUSTAL W and BLAST via http://www.ncbi.nlm.nih.gov, www.bioserving.org. CLUSTAL W is 
a multiple sequence alignment program which calculates the best match for the selected sequences, and lines them up so that similarities and differences can be seen. The Basic local Alignment Search Tool (BLAST) finds regions of local similaritiy between sequences. The program compares nucleotide sequences to the sequence databases and calculates the statistical significance of the matches. BLAST can be used to infer functional and evolutionary relationships between sequences, as well as to identify the members of the gene families. Sequence database from the National Center for Biotechnology Information (NCBI), which was downloaded from http:// www.ncbi.nlm.nih.gov, was used for sequence information on selected $R$. solani isolates (Table 2).

Table.2. Rhizoctonia solani isolates whose ITS sequences were recovered from the GenBank (National Center for Biotechnology Information - $\mathrm{NCBI)}$ and used determining complementarity with tested isolates.

\begin{tabular}{|c|c|c|}
\hline $\begin{array}{l}\text { AG and } \\
\text { subset }\end{array}$ & Host and geographic origin & $\begin{array}{c}\text { GenBank accession } \\
\text { number of ITS sequence }\end{array}$ \\
\hline AG 1-IA & Oryza sativa, Japan & AB000017 \\
\hline AG 1-IB & Beta vulgaris, Japan & AB000038 \\
\hline$A G 1-I C$ & Beta vulgaris, Japan & AB000029 \\
\hline$A G 2-1$ & Solanum tuberosum, USA & AB000026 \\
\hline AG 2-2IIIB & Beta vulgaris, USA & AB054856 \\
\hline AG 2-2 IV & Beta vulgaris, USA & AB054859 \\
\hline AG 2-3 & Glycine max, Japan & U57740 \\
\hline AG 2-4 & Zea mays, USA & AB054878 \\
\hline AG 3 & Beta vulgaris, USA & AB019006 \\
\hline AG 3PT & Solanum tuberosum, USA & AB019013 \\
\hline AG 3TB & Nicotiana tabacum, USA & AB000001 \\
\hline AG $4 \mathrm{HGI}$ & Beta vulgaris, Japan & AB000028 \\
\hline AG 4 HGII & Beta vulgaris, Japan & AB000033 \\
\hline AG 4 HGIII & Beta vulgaris, USA & AF354075 \\
\hline AG 5 & Beta vulgaris, Japan & AF153777 \\
\hline AG 6 & Pterostylis.acuminate,Australia & AF153784 \\
\hline AG 6GV & Soil, Japan & AF354101 \\
\hline AG $6 \mathrm{HGl}$ & Soil, Japan & AG153779 \\
\hline AG 7 & Soil, Japan & AB000003 \\
\hline AG 8 & Triticum aestivum, Australia & AB000011 \\
\hline AG $8 Z G \mid-1$ & Soil, Australia & AF153795 \\
\hline AG $8 Z G \mid-2$ & Soil, Australia & $\mathrm{AF} 153797$ \\
\hline AG $8 Z G \mid-3$ & Hordeum vulgare, Australia & AF354068 \\
\hline AG $8 Z G \mid-4$ & Hordeum vulgare, Scotland & AF354066 \\
\hline AG 9 & Solanum tuberosum, USA & AF354109 \\
\hline AG 9TX & Solanum tuberosum, USA & AB000037 \\
\hline AG 9TP & Solanum tuberosum, USA & AB000046 \\
\hline$A G 10$ & Hordeum vulgare, Australia & AF354071 \\
\hline AG 11 & Glycine max, UAS & AF354114 \\
\hline AG 12 & Pterostylis acuminate, Australia & AF153803 \\
\hline$A G B I$ & Soil, Japan & AB000044 \\
\hline
\end{tabular}


Nour-EL-Din, Mona M.S. et al.

\section{RESULTS AND DISCUSSION}

Rhizoctonia solani fifteen tested isolates in the present investigation, were obtained by regular visits to planted areas belongs to West Delta (Noubaria region) Egypt, Isolates collected from differed host plants showed various symptoms of either stem rot at the soil line, crown rot or root rot.

Three within fifteen isolates (RS.4, RS.5 and RS.6) were only isolated from sugar beet plants wilty foliage or chlorosis and death of the older leaves attached to the crown site.

\section{Pathogenicity tests:}

I. Definition of different modes of disease symptoms were recorded in the first Pathogenicity test on seedlings, where as the three tested isolates were all pathogenic to sugar beet seedlings as well as $R$. solani potatoes competitor isolate (RS.1) examined in the same test, appearing its ability to induce disease symptoms to sugar beet doing moderate mode i.e, $R$. solani isolate (RS.4) seemed to be the most virulent, followed by isolate (RS.6) which was moderately virulent and then isolate (RS.5) respectively, which caused less symptoms to infected seedlings comparing with (RS.1) isolate that obtained from diseased potatoes host and also realized to be moderate pathogen as well as showing similar crown rot symptoms (Table.3.).

The percentage of uninfected plants or healthy seedlings explain these results by meaning that $R$. solani seeds infection caused seeds rot, preventing them to be germinated, invading the coat and cotyledons then destroied them by amylases secretion. Infection also induced seedling wilt or blight, preventing water to move through xylem vessels, which are blocked by pathogen reaction, where by damping-off symptoms have been recorded by each tested isolate.

This results revealed the same findings reported in Egypt by Mahmoud et.al., 2007, who studied 12 isolates of $R$. solani obtained from different diseased hosts collected from various localities in the Nile Delta. They recorded that all isolates were pathogenic and caused seed rot, wilt, stunting and pre and post- emergence damping-off to Phaseolus vulgaris (Giza-6) producing various form of infection cushions that insure the pathogenicity of these examined members.

On the other hand, studies at the University of Minnesota reported that AG 2-2 type of $R$. solani isolates was most highly pathogenic to sugar beets, which can be isolated from pinto bean, soybean and potatoes. Although potatoes may be symptom less host for AG 2-2 isolates which cause damping-off to sugar beet, while of being AG3 type of $R$. solani has the ability of causing damage in potatoes but it is still non pathogenic to sugar beet (Carling \& Leiner, 1990).

Results reported by (Stojsin et al., 2007) who identified four $R$. solani isolates obtained from sugar beet plants, collected from different localities in Vojvodina Province. These isolates showed medium levels of pathogenicity and were able to cause crown and root rot symptoms on inoculated sugar beet roots, comparing with the well-characterized isolate R9, AG 2-2 from the USA. The four examined isolates were shown belong to AG 4 type which in 
general were known to be pathogenic on wide variety of hosts among which was sugar beet.

Table.3. Pathogenicity test of four ( $R$. solani) isolates on sugar beet seedlings.

\begin{tabular}{|l|c|c|c|c|c|c|c|}
\hline \multirow{2}{*}{$\begin{array}{c}\text { Isolates } \\
\text { No. }\end{array}$} & $\begin{array}{c}\text { Seed } \\
\text { rot }\end{array}$ & survival & \multirow{2}{*}{ wilt } & \multicolumn{2}{c|}{ Damping- off } & \multirow{2}{*}{ Healthy } & $\begin{array}{c}\% \\
\text { Healthy }\end{array}$ \\
\cline { 2 - 7 } & & & & $\begin{array}{c}\text { Pre- } \\
\text { emergence }\end{array}$ & $\begin{array}{c}\text { Post- } \\
\text { emergence }\end{array}$ & & \\
\hline RS.1 & 6 & 19 & 8 & 1 & 1 & 9 & 36 \\
\hline RS.4 & 8 & 17 & 12 & 2 & 0 & 3 & 12 \\
\hline RS.5 & 4 & 21 & 3 & 0 & 3 & 15 & 60 \\
\hline RS.6 & 7 & 18 & 6 & 3 & 2 & 7 & 28 \\
\hline Control & 0 & 25 & 0 & 0 & 0 & 25 & 100 \\
\hline
\end{tabular}

Table.4. Effects of different 15 (R. solani) isolates on sugar beet plant.

\begin{tabular}{|l|l|c|c|c|c|c|}
\hline \multirow{2}{*}{$\begin{array}{c}\text { Isolates } \\
\text { No. }\end{array}$} & \multirow{2}{*}{$\begin{array}{c}\text { Isolates } \\
\text { source }\end{array}$} & Chlorosis & Wilting & Stunting & $\begin{array}{c}\text { Crown } \\
\text { rot }\end{array}$ & Root rot \\
\cline { 3 - 7 } & Potatoes & + & + & - & + & - \\
\hline RS.1 & Bean & - & + & - & - & + \\
\hline RS.3 & Pepper & + & + & + & - & - \\
\hline RS.4 & Sugar beet & + & + & + & + & + \\
\hline RS.5 & Sugar beet & + & + & - & + & + \\
\hline RS.6 & Sugar beet & + & + & - & + & + \\
\hline RS.7 & Alfalfa & + & + & - & + & + \\
\hline RS.8 & Pea & - & + & - & + & - \\
\hline RS.9 & Soybean & - & + & - & + & - \\
\hline RS.10 & Soybean & - & + & - & + & - \\
\hline RS.11 & Cucumber & + & + & + & + & + \\
\hline RS.12 & Cucumber & + & + & + & - & + \\
\hline RS.13 & Watermelon & + & + & + & - & - \\
\hline RS.14 & Maize & + & + & + & + & + \\
\hline RS.15 & Maize & + & + & + & + & + \\
\hline
\end{tabular}

So that, causions should paied where Rhizoctonia root rot has been a problem and sugar beet should be grown in rotation with non host crops not more frequently than every third year for avoiding increasing its soil populations.

II. The effect of different $15 R$. solani isolates on sugar beet plants were carried out in the second pathogenicity test, results were expressly presented in (Table 4.) exposured that all fifteen tested isolates of $R$. solani were pathogenic to sugar beet plants, however they did varied symptoms ranked from chlorosis, wilting, stunting, crown rot and root rot. Although $R$. solani was isolated from divergent hosts but some isolates showed similar symptoms pattern, among sugar beet plants. For example, each of $R$. solani isolates No. 4, 5, 6, 7, 11, 14, and 15 as expected to be the most pathogenic isolates, as they caused a completely death to infected sugar beet 
plants.Otherwise, isolates No. 1, 2, 8, 9, 10, and 12, considered to be moderate pathogenic isolates, while more than one disease symptoms could be recorded on the same plant.

On the contrast, less symptoms indicators have been noticed on sugar beet plants infested with each of $R$. solani isolates No. 3 or No.13 (Figure 1.a,b and c).

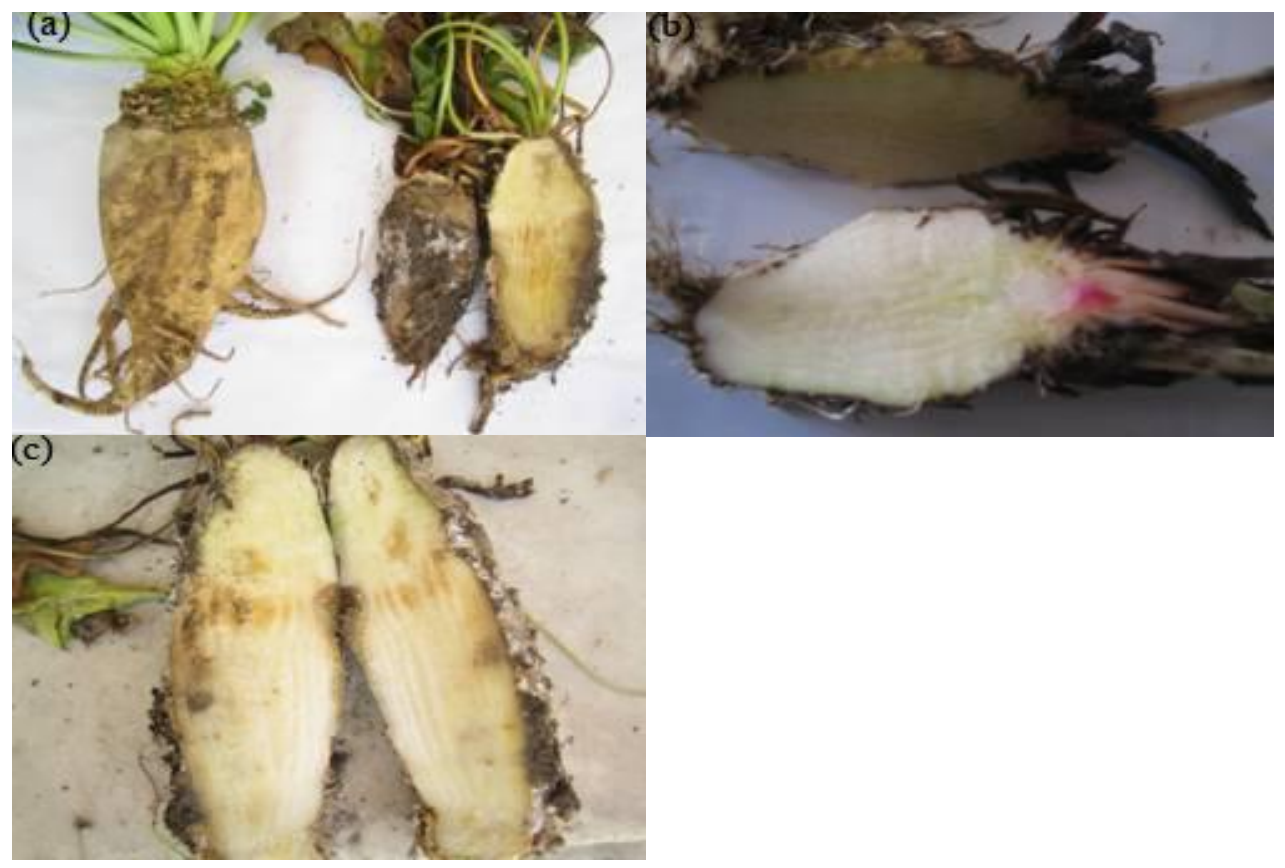

Figure.1. Pathogenicity modes induced by $R$. solani tested isolated on sugar beet plants.

(a) Crown \& root rot with wilting symptoms.

(b) Crown rot \& wilting symptoms.

(c) Root rot symptoms.

This findings were true as some studies have indicated that for sugar beet, potatoes and canola plants, some $R$. solani isolates are typically less virulent, less prevalent or both. They observed differences among strains in the rapidity of lesion progression and modes of pathogenicity under identical condition. So that, they indicated the need for more detailed studied of comparative virulence of the multinucleate isolates and they related these results to the anastomosis groups that are the principal cause of disease on these crops, viz., AG 2-2, AG 3 and AG 4 (Caesar et al., 1993)

This trend was also reported on other crops and location, where $R$. solani isolate (AG 4) was more commonly isolated from soil in carnation fields than other anastomosis groups but was weekly pathogenic compared with AG 2-2 (Trujillo et al., 1988). 
Other studies mentioned that five of six R. solani AG4 isolates, but only two of eight binucleat strains were pathogenic on spurge causing root and crown rot and pre- emergence damping- off in Canada. (Windels \& Nabben, 1989).

\section{Compatibility test :}

In the previous work, mycelial compatibility reaction has been carried to evaluate genetic variability in the studied pathogen in the formation of macroscopic reaction lines (barrages) between the fifteen fungal colonies, interpreted as antagonistic response resulting from the recognition of nonself antigen. Recorded data of compatibility test presented in (Table 5), observed the reactions among the tested isolates against each others.

For incompatible hyphal fusion, as was appeared as a strip of thin mycelium between each two exposed colonies (RS.4 and RS.6) and (RS.5 and RS.15 ) isolates, expressed by(-) negative sing, which means that the both did not anastomose together. In contrast, isolates appeared compatible reaction, i.e. they can anastomose with each other and expressed by $(+)$ positive sign which indicate that they belonged to the same anastomosing group (RS.6 and RS.14) and (RS.14 and RS.15) isolates (Figure 2. a \& b). This result is similar to the data reported by leslie, 1993, Carling et al., 2002 ,Fenille et al.,2003, Mahmoud et al.,2007 and Stojsin et al., 2007, who indicated that, in $R$. solani, the formation of incompatible reaction line (evidenced by a dark line or a strip of thin mycelium and discontinous sclerotia) between pairs of isolates has been observed, which indicated their failure to anastomose.

Results realized by either pathogenicity or compatibility tests indicated that $R$. solani pathogenicity is still complex, it has heterogenous isolates, diversity in host range and generally can invad, attack and decay any part of a plant .



Figure.2.

(a)Compatible reaction (RS.6 \& RS.14) and (RS.14 \& RS.15) R. solani isolates.

(b)Incompatible reaction (RS.4 \& RS.6) and (RS.5 \& RS.15) R. solani isolates. 
Table.5. Mycelial compatibility reaction of $15 R$. solani tested isolates.

\begin{tabular}{|c|c|c|c|c|c|c|c|c|c|c|c|c|c|c|}
\hline Isolate & RS2 & RS3 & RS4 & RS5 & RS6 & RS7 & RS8 & RS9 & RS. 1 & RS11 & RS1 & 3S1 & RS1 & RS15 \\
\hline RS.1 & + & - & - & - & - & + & - & + & + & - & - & + & + & + \\
\hline RS.2 & & + & + & + & - & + & + & + & + & + & + & + & + & + \\
\hline RS.3 & & & - & - & - & - & - & + & + & - & - & + & + & - \\
\hline RS.4 & & & & + & - & - & - & - & + & + & - & + & - & - \\
\hline RS.5 & & & & & - & - & + & + & + & + & + & + & + & - \\
\hline RS.6 & & & & & & + & + & - & - & - & - & + & + & + \\
\hline RS.7 & & & & & & & + & + & + & + & - & + & + & - \\
\hline RS.8 & & & & & & & & + & + & + & - & + & + & + \\
\hline RS.9 & & & & & & & & & + & + & + & + & + & - \\
\hline RS.10 & & & & & & & & & & + & + & + & + & - \\
\hline RS.11 & & & & & & & & & & & + & + & + & - \\
\hline RS.12 & & & & & & & & & & & & + & + & + \\
\hline RS.13 & & & & & & & & & & & & & + & - \\
\hline RS.14 & & & & & & & & & & & & & & + \\
\hline
\end{tabular}

(+): Compatibile hyphal reaction.

$(-)$ : Incompatibile reaction.

Recently, biochemical and molecular markers are considered important tools for studing this genetic diversity of pathogens in which morphological characteristics are not adequate to properly distinguish different isolates(Sharma et al., 2005). Consequently, problems related to studying various levels of genetic diversity in $\mathrm{R}$. solani have been proposed to be best solved by the employment of molecular techniques. In the present work we had to group those 15 tested isolates in to anastomosis groups, i.e., AG types, inorder to clear its relationship, whereas they seemed to be genetical separated a meaning to be classified into different groups.

Results presented in (Figure 3 ) and after PCR reaction, the presence of amplified product were tested by running an agarose gel in TBE buffer. DNA bands were approximately $740-750$ base pairs long.

Ribosomal DNA Sequence analysis:

Sequencing of rDNA of tested 15 isolates showed that size of the ITS region varied from 713 - 716 base pairs and their sequencing were identical $(100 \%)$ in the ITS region. The ITS sequences of tested isolates of $R$. solani, which belonged to AG1-12 and AGBI were recovered from the Gen Bank (Table 2). The comparison between sequences registered in Gen Bank and Egyptian tested isolates showed that all isolates had sequences homology between 84 and 99\% with the referent isolates (Figure 4. a \& b).

So that, the study observed the efficiency of ITS sequencing as a powerful tool in under standing and determinating the relationship between anastomosing groups of $R$. solani. Techniques which rely on molecular markers are more accurate easier and more rapid than conventional methods for detection anastomosis group. Sequencing analysis of the tested isolates (RS.4, $6,7,9,12,14$, and 15 ) separated them into two clusters or groups . The first group included 6 isolates with more genetic similarity of approximately $99 \%$.

The second group included only one isolate ( RS.4 ), i.e. data revealed that the ITS sequence analysis of the tested isolate RS.4 and RS.5 just belonged 
to R.solani group (AG 2-2 ) which is highly virulent inducing Rhizoctonia crown and root rot to sugar beet and are typically characterized as naturally infection symptoms. These isolates also caused damping-off symptoms to seedlings, besides being classified into intraspecific group IV which is found world wide, although AG 2-2 IIIB is more common on sugar beet in Europe in rotation with maize (Jacobsen, 2005). This sequencing data analysis confirmed the results observed by compatibility reaction, where the mentioned tested isolates having the ability to anastomose together $(+)$ (Table 5), instead of being (RS.5 ) causing similar symptoms but less comparing with (RS.6) which is moderately virulent but classified into another different group ( $\mathrm{AG} 4 \mathrm{HGI}$ ). So, data suggest that isolate ( RS.5) is very closed or related to (RS.4) and it could classified into the same group (AG22 ) . The same data records have detected for other tested isolates RS.6, RS.7,RS.9,RS.12, RS.14 and RS.15 respectively, whose observed high pathogenicity ratio like that almost characterized by RS. 4 isolate, whereas its ITS sequences of rDNA analysis revealed gentic similarity data that are they related to anastomosis group AG4HGI, i.e., data has been objected by incompatibility reaction, where, The mentioned tested isolates (RS.6, RS.7,RS.9,RS.12, RS.14 and RS.15) can not anastomose (-) with (RS.4) tested isolate (Table 5) which related to differ group (AG 2-2) . By using Gen Bank accession number of ITS sequence of the two comparible groups, percentage of similarity recorded $99 \%$ between ( RS.12 \& each of RS.6,9,12,14, and 15 ) isolates and between (RS.6,9,14, and 15 )isolates respectively (Figure 4 .b) .

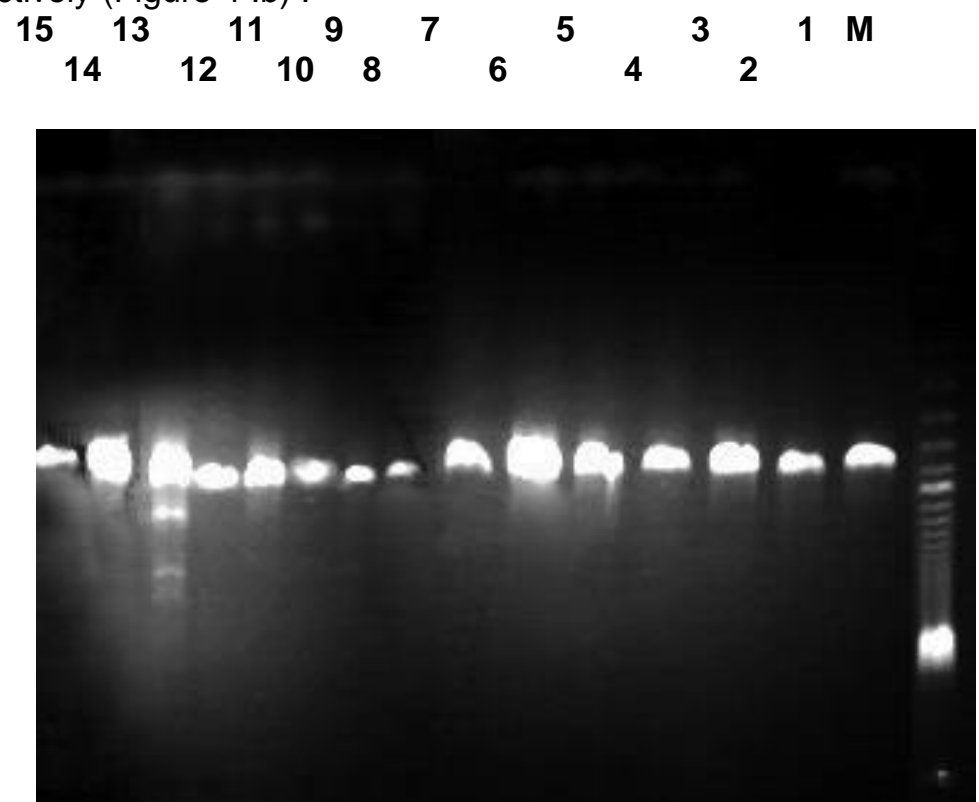

Figure.3. Amplification of DNA from $15 R$. solani isolates with primers ITS 1F and ITS4 shows bands 750 base pairs long (line1: 100bp marker), (line 2: RS.1) and (line $16:$ RS.15) from right to left. 

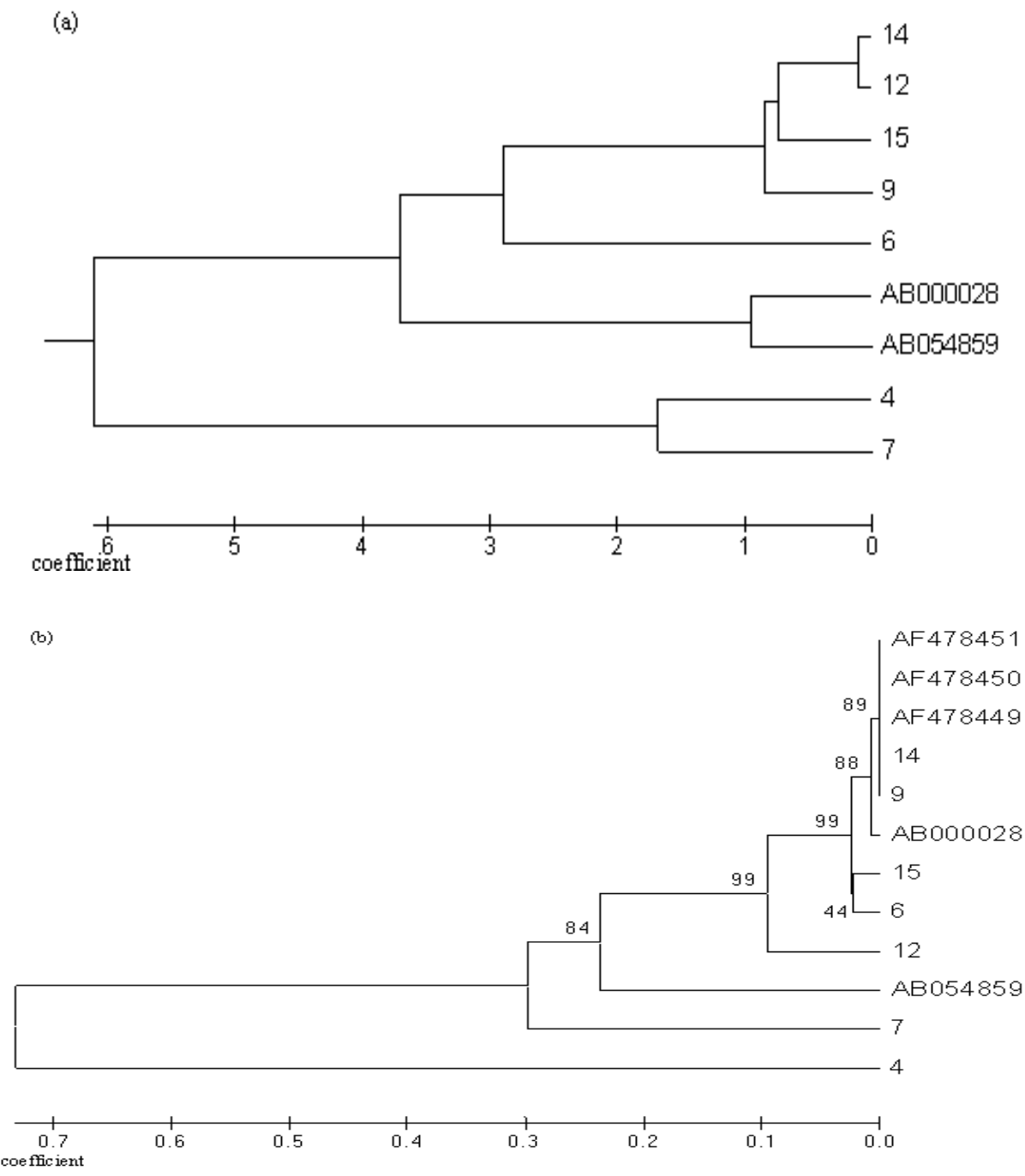

Figure.4.

(a) Dendrogram obtained from seven tested isolates of $R$. solani Branches are labeled by isolate number $(4,6,7,9,12,14$, and 15) and Gen Bank accession number of ITS sequence of rDNA for two $A_{s}$ [AG2-2 IV (AB054859) \& AG4HGI (AB000028)], used for determining complementarity.

(b) Phylogenetic tree showing relationship between ITS sequence of rDNA of seven $R$. solani tested isolates.(the neighbor-joining method Saitou and Nei. 1987). 
Percentage of sequence similarity has been detected in dendrogram (Figure 4.b ) where relatedness recordness recorded $84 \%$ between RS.7 isolate and the remainder tested isolates (RS.6,9,12,14 and 15 ), instead it revealed to be belonged to the same group (AG4HGI ) Kumar et al.,2004 . In general reports mentioned by (Kuninaga,et al., 1997) AG4 isolates are known to be pathogenic on wide variety hosts, among which is sugar beet (Windels and Nabben, 1989).

Besides sequencing of the ITS part of the rDNA, other molecular biology technique have been developed, as restriction fragment length polymorphism (RFLP) analysis of ITS region of rDNA which carried out as rapid and accurate analysis of large number of $R$. solani isolates (Guillemaut et al., 2003). In this study we used this technique to be another assessor, very fast technique for differences detection between AGs of tested isolates as it reported by (Duncun et al.,1993). Data analysis has proven in this instance to be an excellent tool for identification of those isolates or grouping them into two main groups (AG2-2 IV ) \& ( AG4 HGI). Once, the aim of the research was to analyse the less conserved part of rDNA region, since it is proven that $5.8 \mathrm{~s} r$ DNA sequences show significant differences between AGs (Fenille et al.,2003).

\section{CONCLUTION}

This research denoted the importance of identifying the correct anastomosis group (AG) of $R$. solani associated with crown and root rot of sugar beet. The ability of analysing the ITS region of rDNA to genotype of the tested isolates as compared to the anastomosis reaction method were assessed and to analyse the distribution of genetic diversity among isolates of this pathogen. While AG reaction sensitivity it did provide, we would not recommend it alone for isolates identifying. The analysing of ITS sequence of rDNA to tested isolates is still highly sensitive technique and Labour-efficient than AG typing, since the host range of AG 2-2 are much different than AG 4. AG 2-2 has host range reported as sugar beet, bean, soybean, maize, rice, ginger, turf grasses, gladiolus, chrysanthemum and Chinese yam, whereas, AG 4 recorded hosts as sugar beet, pea, tomato, potato, spinach, snap bean and loblolly pin. This variation can affect the recommended crop rotation used to control partially the crown and root rot disease of sugar beet. Potato crop was considered to be a suitable host for $R$ solani $A G 3$, and anastomosing group 4 could isolated from symptomless ones but certainly not for AG 2-2. 


\section{REFERENCES}

Banniza, s. and Rutherford, M.A. (2001). Diversity of isolates of Rhizoctonia solani AG1-1A and their relationship to other anastomsis groups based on pectic zymograms and molecular analysis. Mycol. Res. 105:33-40.

Caesar, A.J., Rees, N.E., Spencer, N.R. and Quimby, J.R. (1993) Characterization of Rhizoctonia spp. Causing disease of leafy spurge in the Northern plains. Plant Dis. 77:681-684.

Carling, D.E., Kuninaga, S., Brainard, K.A. (2002). Hyphal Anastomosis Reactions, rDNA- Internal Transcribed Spacer Sequences, and virulence levels Among subsets of Rhizoctonia solani Anastomosis Groups-2 (AG-2) and AG-BI, Phytopathology 92:43-50.

Carling, D.E.,and Leiner,R.H. (1990). Virulence of isolates of Rhizoctonia solani AG-3 collected from potato plant organs and soil. Plant Dis.47:901-903.

Duncun,S.,Barton,J.A. and O'Brien,P.A.(1993).Analysis of variation in isolates of Rhizoctonia solani by random amplified polymorphic DNA assay, Mycol. Res.97:1075-1082.

Earnshaw, D. and Boland, G. (1997) Mycelial compatibility groups in sclerotium cepivorum. Plant pathology. 46:229-238.

Fenille, R.C., Ciampi, M.B., Kuramae, E.E. and Souza, N.I (2003). Identification of Rhizoctonia solani associated with soybean in Brazil by rDNA- ITS sequences, Fitopatogia Brasileria 28:413-419.

Gonzales, D., Cubeta, M.A. and vilgalys, R. (2006). Phylogenetic utility of indels within ribosomal DNA and beta - tubulin sequences from fungi in the Rhizoctonia solani species complex, Mol. Phylogenet. Evol. 40(2), 459-470.

Guillemaut, C., Edel- Herman, V., Camporota, P., Alabouvette, C., RichardMolard, M. and Steinberg, C. (2003) Typing of anastomosis groups of Rhizoctonia solani by restriction analysis of ribosomal DNA, Can. J. Microbiol. 49:556-568.

Innis, M.A., and D.H. Gelfand. (1991). Optimization of PCRs, p. 3-12. In M.A. Innis, D.H. Gelfand, J.J. Sninsky, and T.J. white (ed.), PCR protocols, a guide to methods and applications. Academic Press, San Diego, California.

Jacobsen, J.B. (2005). Root. Rot diseases of sugar beet, proceeding for Natural sciences, Matica Srpska, Novi sad, No. 110:9-19.

Kumar, S.,Tamura,K.and Nei,M. (2004). MEGA3:Integrated software for molecular evolutionary gentics analysis and sequence alignment .Briefings in Bioinformaties.5:150,163.

Kuninaga, S., Carling, D.E., Takeuchi, T. and Yokosawa, R. (2000). Comparison of rDNA ITS sequence between potato and tobacco strains in Rhizoctonia solani AG-3. Journal of General plant pathology. 66:2-11.

Kuninaga, S., Natsuaki, T., Takeuchi, T. and Yokosawa, R. (1997). Sequence variation of the rDNA ITS region within and between anastomosis groups in Rhizoctonia solani. Current Genetics. 32:237-243. 
Lesile, JF.(1993). Fungal vegetative compatibility. Annual Rev.of Phytopathology.31:127-150.

Liu, Z. L., Domier, L.L. and Sinclair, J.B. (1995). Polymorphism of genes coding for nuclear 185 rRNA indicates genetic distinctiveness of anastomosis group 10 from other groups in the Rhizoctonia solani species complex. Appl. Environ. Microbiol. 61:2659-2664.

Mahmoud, Y.A.G, Gaafar, R.M. and Mubarak, H.M. (2007). Genetic Diversity among Nile Delta isolates of Rhizoctonia solani Khün based on pathogenicity, compatibility, isozyme Analysis and total protein pattern. Turk. J. Bot. 31:19-29

Saitou,N. and Nei,M.(1987). The neighbour, joining method :a new method for reconstructing phylogentic trees .Mol.Biol.Evol.4:406-425.

Sharma,M.,Gubta,SK.and Sharma,TR.(2005). Characerization of variability in Rhizoctonia solani by using morphological and molecular markers . J. Phytopathololgy.153:449-456.

Stojsin, V., Bodakov, D., Jacobsen, B., Grimme, E., Bagi, F. and Jasin, S. (2007). Identification of Rhizoctonia solani isolates from sugar beet roots by analysis The ITS region of ribosomal DNA. Proceedings for Natural sciences, matica Srpska, Novi Sad, No. 113, 161-171.

Trujillo, E.E., Shimabuku, R., Cavin, C.A. and Aragaki, M. (1988) Rhizoctonia solani anastomosis grouping in carnation field and their pathogenicity to carnation. Plant Dis. 72: (863-865).

whitney, E.D. and Duffus, J.E. (1986). Compendium of Beet Diseases. American Phytopathological Society. St. Paul, MN. 67pp.

Windels, C.E. and Nabben, D.J. (1989). Characterization and pathogenicity of anastomosis groups of Rhizoctonia solani isolates from Beta vulgaris, phytopathology. 79:83-88.

Windels, C.E., Kuznia, R.A. and Call, J. (1997). Characterization and pathogenicity of Thanatophorus cucumeris from sugar beet in Minnesota, Plant Dis. 81:245-249. 
دراسة التباين في عزلات الفطر ريزوكتونيا سولاني لبنجر السكر بإستخدام تكنيك تفاعل البلمرة المتسلسل (rDNA-ITS).

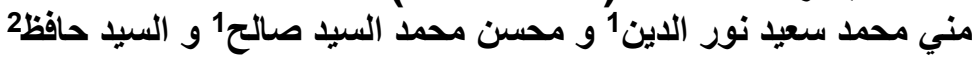

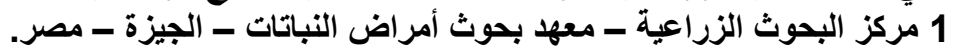
2 مدينة مبارك للأبحاث العلمية ـ معهد بحوث الأراضي الجافة - إسكندرية ـ مصر.

إختبرت خمسـة عشر عزلنة للفطر ريزوكتونيا سو لاني المعزول بعضهـا من نباتـات بنجر

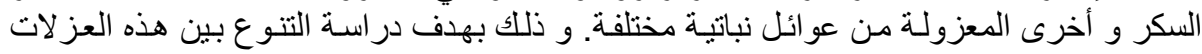

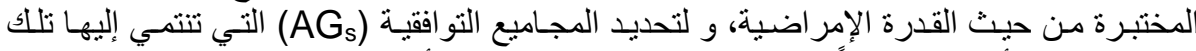

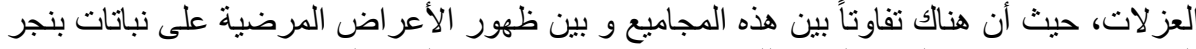

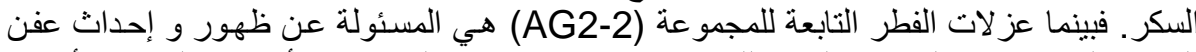

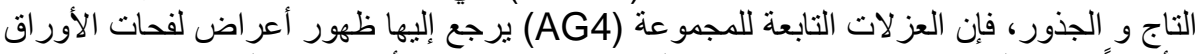

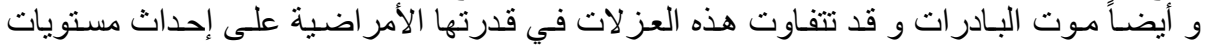

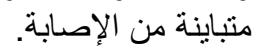

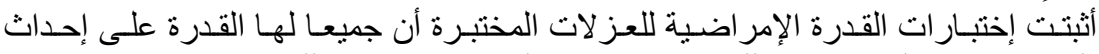

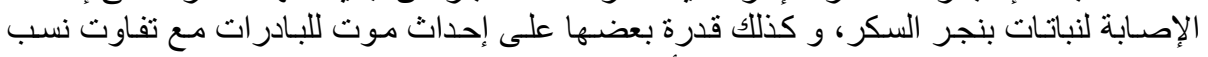

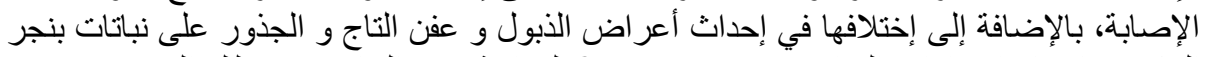

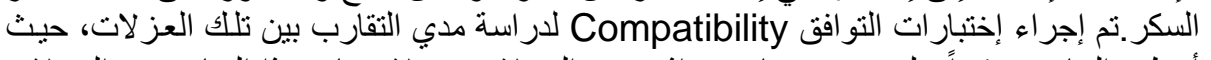

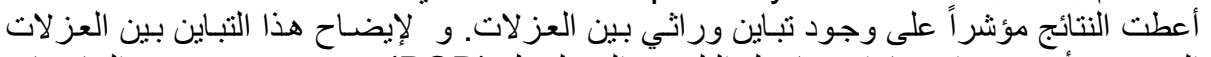

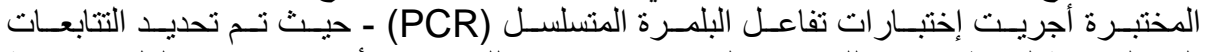

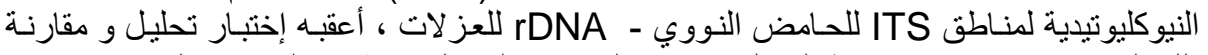

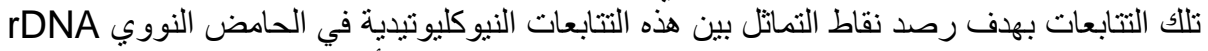

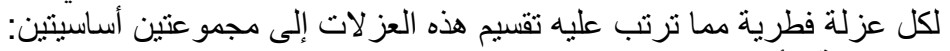

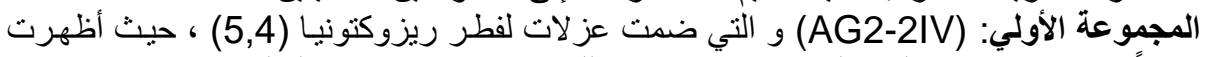

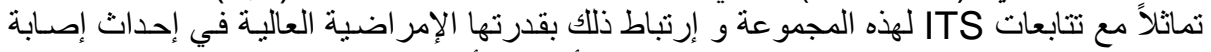

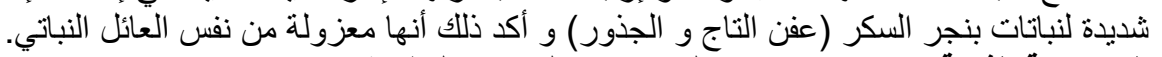

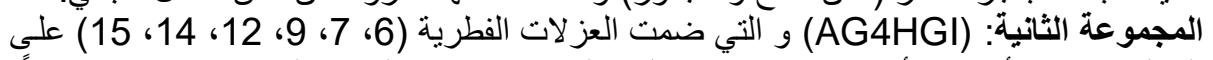

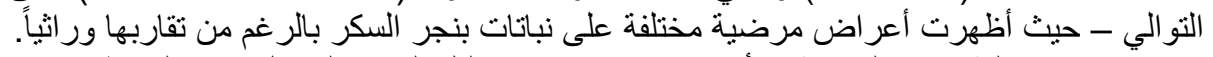

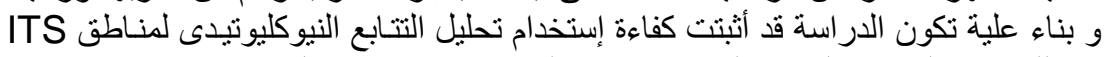
في rDNA للعز لات المختبرة لتحديد العلاقة و نسب التقارب بين عزلاء لات الفطر ريزوكتونيا سو لانى 